\title{
Reduction of Chilling Injury of 'Nam Dok Mai No. 4' Mango Fruit by Treatments with Salicylic Acid and Methyl Jasmonate
}

\author{
Chanikan Junmatong ${ }^{1}$, Jamnong Uthaibutra ${ }^{1,2}$, Danai Boonyakiat ${ }^{2,3}$, Bualuang Faiyue ${ }^{4} \&$ Kobkiat Saengnil $^{1,2}$ \\ ${ }^{1}$ Department of Biology, Faculty of Science, Chiang Mai University, Chiang Mai, Thailand \\ ${ }^{2}$ Postharvest Technology Research Institute, Chiang Mai University/ Postharvest Technology Innovation Center, \\ Commission on Higher Education, Bangkok, Thailand \\ ${ }^{3}$ Department of Plant Science and Natural Resources, Faculty of Agriculture, Chiang Mai University, Chiang Mai, \\ Thailand \\ ${ }^{4}$ Department of Biology, Mahidol Wittayanusorn School, Salaya, Phutthamonthon, Nakhon Pathom, Thailand \\ Correspondence: Kobkiat Saengnil, Department of Biology, Faculty of Science, Chiang Mai University, Chiang \\ Mai 50200, Thailand. Tel: 66-5394-3346-60 ext.1205. E-mail: kobkiat_s@hotmail.com
}

Received: June 7, 2012 Accepted: July 3, 2012 Online Published: August 24, 2012

doi:10.5539/jas.v4n10p126

URL: http://dx.doi.org/10.5539/jas.v4n10p126

\begin{abstract}
This study determined the effects of salicylic acid (SA) and methyl jasmonate (MJ) on chilling injury (CI) of stored mangoes at low temperature. Mango fruits cv. Nam Dok Mai No.4 were dipped in SA and MJ at concentrations of 0.1 and $1 \mathrm{mM}$ for 10 minutes and stored at $5 \pm 1{ }^{\circ} \mathrm{C}$ with $90 \pm 2 \% \mathrm{RH}$ for 42 days. Fruits were sampled every 7 days to determine the $\mathrm{CI}$ index, malondialdehyde (MDA) content, electrolyte leakage (EL), then transferred to room temperature $\left(25 \pm 2{ }^{\circ} \mathrm{C}, 70 \pm 2 \% \mathrm{RH}\right)$ for ripening and analyzed for $\mathrm{CI}$ index, MDA content, $\mathrm{EL}$, and ripening quality. The results show that mango fruits showed CI symptoms after 21 days of storage at $5{ }^{\circ} \mathrm{C}$ and were unacceptable for consumption after 28 days of cold storage and after transfer to room temperature. SA and MJ treatments significantly reduced CI, MDA content, and EL in the mango skin and pulp during cold storage and after transfer to room temperature. Dipping fruits in $0.1 \mathrm{mM} \mathrm{MJ}, 1 \mathrm{mM} \mathrm{MJ}$, and $0.1 \mathrm{mM}$ SA reduced $\mathrm{CI}$ of cold storage and after transfer to room temperature up to 35 days, whereas dipping in $1 \mathrm{mM}$ SA prolonged this up to 42 days without affecting fruit firmness, percentages of TA, and skin color ( ${ }^{\circ} \mathrm{Hue}$ values) of the ripe fruits.
\end{abstract}

Keywords: chilling injury index, cold storage, electrolyte leakage, malondialdehyde, Mangifera indica, ripening

\section{Introduction}

Mango (Mangifera indica L.) is an economic fruit grown throughout Thailand. It is domestically consumed and exported to international markets. Among mango cultivars, Nam Dok Mai is the most popular with lusciously fragrant sweet juicy flesh and golden yellow skin color that attracts consumers. Harvested mangoes ripen and deteriorate quickly at ambient temperature (Zhao et al., 2006; Ding et al., 2007), leading to a short postharvest life and an export problem. Low temperature storage is considered to be the most effective method of extending postharvest life and maintaining the quality of the fruits (Wills et al., 1998). Keeping mangoes under low temperatures causes chilling injury $(\mathrm{CI})$, the symptoms of which include skin surface pitting, sunken lesions, skin browning and pulp discoloration, and the symptoms become more serious when fruits are transferred to room temperature (González-Aguilar et al., 2000, 2001; Zhao et al., 2006; Ding et al., 2007; Wang et al., 2008). Chilled mangoes have a less desirable aroma and flavor after transfer to room temperature for ripening (Mohammed \& Brecht, 2002). Such symptoms are dependent on the cultivar, degree of maturity, time and temperature of exposure, and environmental conditions during and after low temperature storage (Mohammed \& Brecht, 2002; Phakawatmongkol et al., 2004; Lim et al., 2009). It has been reported that mango fruit cv. Nam Dok Mai is very susceptible to CI when stored at cold temperature such as $12{ }^{\circ} \mathrm{C}$ (Phakawatmongkol et al., 2004). This development of CI symptoms reduces customer acceptance and limits the storage life of the fruits.

CI causes membrane damage via oxidation of membrane lipids, leading to structural changes and increased membrane permeability (Zhao et al., 2006). Malondialdehyde (MDA) content and electrolyte leakage (EL) are 
used to indicate lipid peroxidation of membrane lipids and membrane permeability, respectively, which increase during low temperature storage (Zhao et al., 2006). Various methods, such as modified atmosphere packaging (Kumpoun and Uthaibutra, 2010), cold-shock treatment (Zhao et al., 2006) and application of plant growth regulators (PGRs) (Ding et al., 2007) have been applied to mango fruits to alleviate CI symptoms. Among those methods, application of PGRs is easy to set up and inexpensive (Cao et al., 2009; Jin et al., 2009; Sayyari et al., 2009).

Salicylic acid (SA) and methyl jasmonate (MJ) are plant hormones and endogenous signal molecules that have important roles in responses to environment stresses (Raskin, 1992; Creelman and Mullet, 1997; Ananieva et al., 2004; Wang et al., 2006). It has been reported that SA and MJ treatments could be used to reduce deterioration and the development of $\mathrm{CI}$ symptoms in three cultivars of mango: Tommy Atkins, Kent, and Zill (González-Aguilar et al., 2000, 2001; Ding et al., 2007) and other fruits such as guava (Psidium guajava), loquat (Eriobotrya japonica L.), peach (Prunus persica L.) and pomegranate (Punica granatum) (González-Aguilar et al., 2004; Cao et al., 2009; Meng et al., 2009; Sayyari et al., 2009).

Although SA and MJ have been shown to alleviate CI symptoms in mango fruits, there have rarely been studies on Thai mangoes. The objective of our study was to determine (1) the effects of SA and MJ on CI symptoms of Nam Dok Mai No. 4 mango fruits during cold storage and after transfer to room temperature and (2) the effects of SA and MJ on ripening quality of Nam Dok Mai No. 4 mango fruits after transfer to room temperature.

\section{Materials and Methods}

\subsection{Plant Materials}

Mango fruits cv. Nam Dok Mai No. 4 at the harvest stage were obtained from a commercial orchard in Noen Maprang district, Phitsanulok province, Thailand, and transported to the Postharvest Physiology and Technology Research Laboratory at Chiang Mai University within 6 hours of harvest. Fruits were cleaned with tap water, separated by size and color, cleaned in a solution of $0.06 \mathrm{mM}$ azoxystrobin for 30 seconds, and dried in air at ambient temperature. The fruits were randomly divided into five groups of 84 fruits each and each group was dipped in solutions of $0.1 \mathrm{mM} \mathrm{SA}, 1 \mathrm{mM} \mathrm{SA}, 0.1 \mathrm{mM} \mathrm{MJ}, 1 \mathrm{mM} \mathrm{MJ}$ or distilled water (as a control) for 10 minutes. After dipping, fruits were air-dried for 30 minutes, packed in corrugated cardboard boxes (12 fruits per box), and then stored at $5 \pm 1{ }^{\circ} \mathrm{C}$ with a relative humidity (RH) of $90 \pm 2 \%$ for 42 days. Twelve fruits from each treatment were randomly sampled every 7 days. Six fruits were evaluated for changes in CI index, MDA content, and EL. The other six fruits were transferred to room temperature $\left(25 \pm 2{ }^{\circ} \mathrm{C}, 70 \pm 2 \% \mathrm{RH}\right)$, and allowed to ripen. Ripening quality including the number of days to ripen, skin color, firmness, TSS, TA, disease index, consumer acceptance, and the same parameters as mentioned above were measured.

\subsection{Chilling Injury (CI) Index}

The degree of CI was indicated using the CI index, as described by Zhao et al. (2006) with slight modifications. The CI score was assessed on the percentage of surface area affected by browning on the skin compared with total surface area, where $0=$ no visible browning area, $1=1-10 \%$ browning area, $2=11-25 \%$ browning area, $3=26-50 \%$ browning area, $4=51-75 \%$ browning area, and $5=>75 \%$ browning area. The CI index was determined for each treatment by multiplying the number of fruits in each category with their score, and then dividing this by the total number of fruit assessed. Fruits having a $\mathrm{CI}$ index above 2 were considered as unacceptable for visual marketing quality.

\subsection{Malondialdehyde (MDA) Content}

The MDA content in mango skin and pulp was measured according to the method of Hodges et al. (1999). Frozen tissue $(1 \mathrm{~g})$ was homogenized in $5 \mathrm{ml}$ of $0.1 \%(\mathrm{w} / \mathrm{v})$ trichloroacetic acid (TCA) by using a mortar and pestle. The homogenate was centrifuged at $10000 \times \mathrm{g}$ for 20 minutes (Biofuge pico, Sorvall, Germany). Then $0.5 \mathrm{ml}$ of $20 \%$ TCA containing $0.5 \%(\mathrm{w} / \mathrm{v})$ thiobarbituric acid (TBA) was mixed with $0.5 \mathrm{ml}$ of supernatant. The mixture was heated in boiling water for 10 minutes, cooled to room temperature, and centrifuged at $10000 \times \mathrm{g}$ for 5 minutes. The absorbance of the supernatant was measured at $532 \mathrm{~nm}$ by a visible spectrophotometer (Genesys 20 , Thermo Scientific, USA) and corrected for nonspecific turbidity by subtracting the absorbance at $600 \mathrm{~nm}$. The amount of MDA was calculated from the extinction coefficient of $155 \mathrm{mM}^{-1} \mathrm{~cm}^{-1}$ and expressed as $\mathrm{nmol} / \mathrm{g}$ fresh weight.

\subsection{Electrolyte Leakage (EL)}

EL was measured according to the method of Chan et al. (1985), with slight modifications. Ten discs, taken with a cork borer $(10 \mathrm{~mm}$ diameter) from skin and pulp tissue, were placed in an Erlenmeyer flask with $25 \mathrm{ml}$ deionised water. After 30 minutes at $25^{\circ} \mathrm{C}$, conductivity was measured with a conductivity meter (FiveEasy FE 30, 
Mettler Toledo, Switzerland). The Erlenmeyer flask was heated at $98{ }^{\circ} \mathrm{C}$ for 15 minutes. The conductivity was re-measured after cooling. Membrane permeability units were calculated as: $\% \mathrm{EL}=$ (ion leakage at $25{ }^{\circ} \mathrm{C} /$ ion leakage at $\left.98^{\circ} \mathrm{C}\right) \times 100$.

\subsection{Ripening Quality}

The number of days required to ripen mangoes was counted when fruits were transferred to room temperature.

Skin color of ripe fruits was determined using a chromameter (MiniScan XE Plus, HunterLab, U.S.A.) and expressed as ${ }^{\circ} \mathrm{Hue}$ values (CIE 1976). ${ }^{\circ} \mathrm{Hue}$ values indicate skin color ranging from 0-360 in which the value of 0,90 , and 180 indicates red, yellow, and green, respectively.

Flesh firmness was determined using a firmness tester (Hunter Spring LKG-10, AMETEK, U.S.A.) with a diameter tip of $11 \mathrm{~mm}$.

TSS content was determined using a pocket refractometer (PAL-1, ATAGO, Japan).

TA content was determined by titrating fruit juice with $0.1 \mathrm{~N} \mathrm{NaOH}$ according to AOAC (1990) procedures and expressed as percentage of citric acid per volume of fruit juice.

The degree of disease in fruits was indicated, using a disease index (DI) based on external damage on the skin (Wang et al., 2008). The disease score was assessed by the percentage of total surface area affected by disease, where $0=$ no visible diseased, $1=\leq 25 \%$ diseased area, $2=26-50 \%$ diseased area, $3=51-75 \%$ diseased area, and $4=>75 \%$ diseased area. The DI was determined for each treatment by multiplying the number of fruits in each category with their score and then dividing this by total number of fruits assessed.

Consumer acceptance for texture, taste, appearance, and odor of ripe mangoes was evaluated by a trained panel of 5 people using a nine-point hedonic scale in which 1 was the lowest acceptance, whereas 9 was the highest (Wang et al., 2008). An average of score more than six was considered as acceptable for consumption. The qualities of ripe fruits after transfer from cold storage were compared with fruits ripened normally at room temperature.

\subsection{Statistical Analysis}

Experiments were performed using a completely randomized design and were repeated three times. Statistical analysis was carried out using SPSS version 17 (SPSS incorporation Chicago, IL, USA). Tukey's Multiple Range Tests $(P=0.05)$ were performed to determine significant differences among the treatments.

\section{Results}

\subsection{Chilling Injury during Cold Storage}

During cold storage at $5{ }^{\circ} \mathrm{C}$, CI symptom, such as skin browning, indicated by the CI index, of Nam Dok Mai No. 4 mango fruits started to appear after 21 days and progressed in fruits stored for longer periods (Figure 1). At 35 and 42 days, in addition to skin browning, fruits also showed symptoms of surface pitting and endocarp browning (data not shown). Fruits treated with either SA or MJ at concentrations of 0.1 and $1.0 \mathrm{mM}$ had significantly lower $\mathrm{CI}$ indices and significantly less severe CI symptoms (Figure 1). At 42 days, the CI index was significantly reduced by $20 \%, 70 \%$ and $20 \%$, in fruits treated with $0.1 \mathrm{mM} \mathrm{SA}, 1.0 \mathrm{mM} \mathrm{SA}$ and $0.1 \mathrm{mM} \mathrm{MJ}$, respectively, compared with the control (Figure 1). Among the treatments, $1.0 \mathrm{mM} \mathrm{SA}$ was the most effective at reducing the CI index (Figure 1).

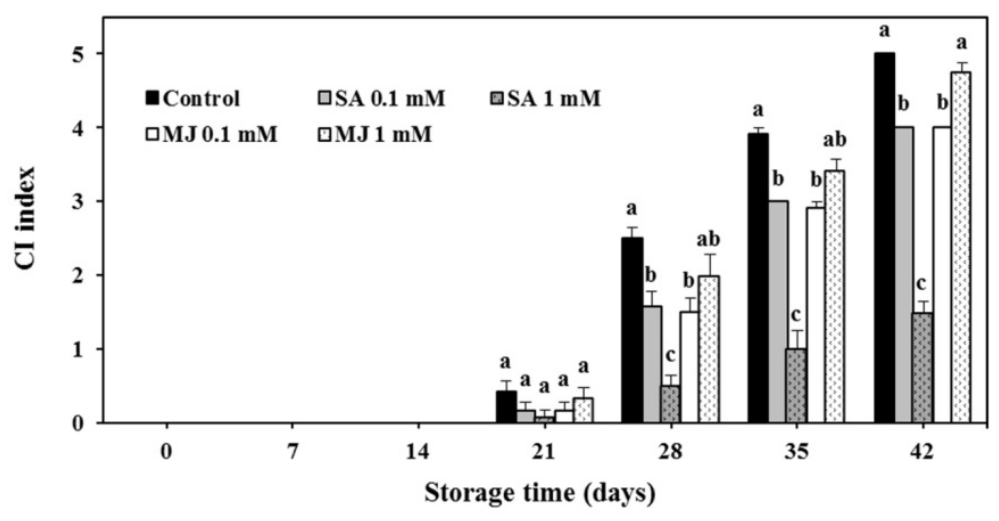

Figure 1. Effects of SA and MJ on chilling injury (CI) index of mango fruits during storage at $5{ }^{\circ} \mathrm{C}$ 


\subsection{MDA Content during Cold Storage}

During cold storage at $5{ }^{\circ} \mathrm{C}$, MDA content in the skin and pulp (Figures 2a, and b) significantly increased in the control fruits. This increase in MDA content was reduced when fruits were treated with SA and MJ. At 42 days, the MDA content in the skin of mango fruits treated with 0.1 and $1 \mathrm{mM} \mathrm{SA}$ was lower than that of the control by 7.7 and $22.5 \%$, respectively, whereas MDA content was reduced by 13.9 and $6.8 \%$ when fruits were treated with 0.1 and $1 \mathrm{mM}$ MJ, respectively. In the pulp, the MDA content of fruits treated with 0.1 and $1 \mathrm{mM} \mathrm{SA}$ was lower than that of the control by 19.2 and $33.6 \%$, respectively, at 42 days, while for fruits treated with 0.1 and $1 \mathrm{mM}$ MJ, it was 18.5 and $10.5 \%$ lower compared with the controls. The treatment of $1 \mathrm{mM}$ SA was the most efficient at reducing MDA content in both the skin and pulp.

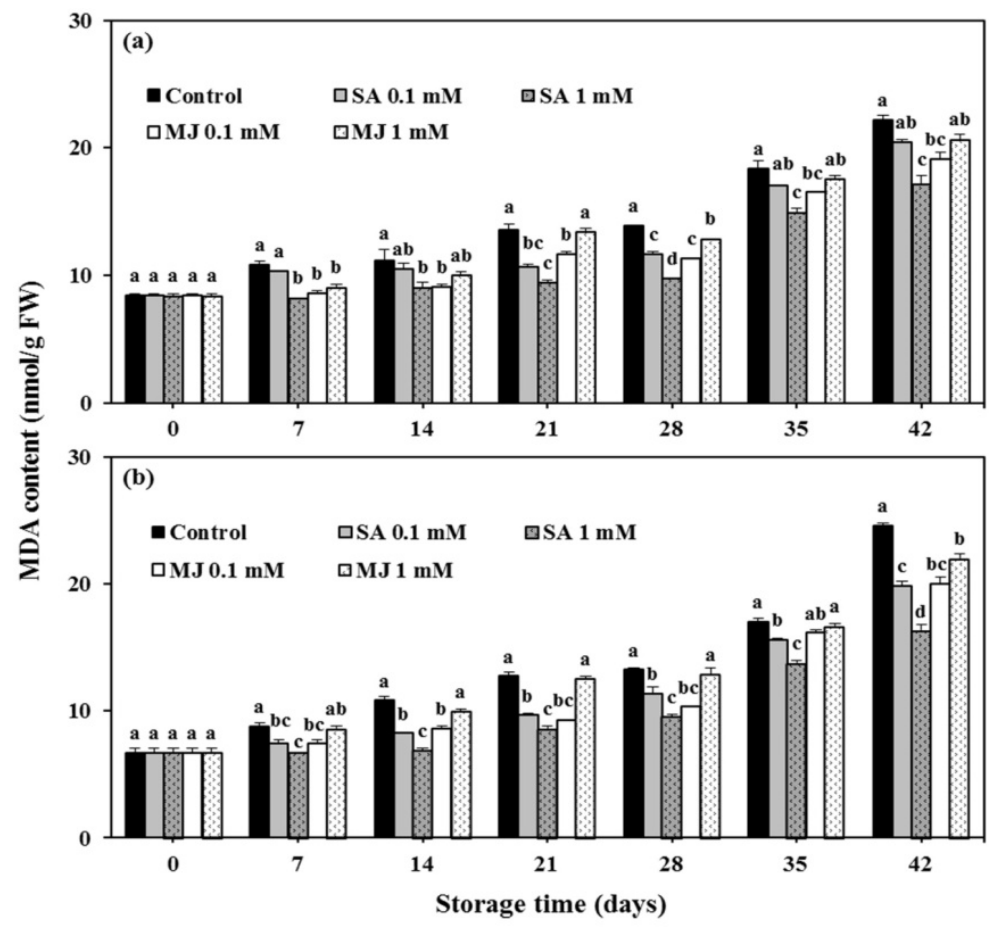

Figure 2. Effects of SA and MJ on malondialdehyde (MDA) content in the skin (a) and pulp (b) of mango fruits during storage at $5{ }^{\circ} \mathrm{C}$

\subsection{EL during Cold Storage}

During cold storage at $5{ }^{\circ} \mathrm{C}$ for 42 days, EL in Nam Dok Mai No. 4 increased slightly in the skin and pulp (Figures 3a, and b). This increase of EL was reduced by MJ and SA treatments. In the skin, EL of fruits treated with 0.1 and $1 \mathrm{mM} \mathrm{SA}$ was lower than the control by 13.6 and $25.1 \%$, respectively, at 42 days after storage, whereas EL of fruits treated with 0.1 and $1 \mathrm{mM}$ MJ was 13.1 and $2.8 \%$ lower than that of the control (Figure 3a). In the pulp, EL of fruits treated with 0.1 and $1 \mathrm{mM} \mathrm{SA}$ was 13.9 and $19.7 \%$ lower than that of the control at 42 days, whereas in fruits treated with 0.1 and $1 \mathrm{mM} \mathrm{MJ}$, EL was reduced by 10.6 and $4.7 \%$, respectively (Figure $3 \mathrm{~b}$ ).

\subsection{CI after Transfer to Room Temperature}

The CI of ripe mango fruits started after cold storage for 21 days and progressed in fruits stored for longer periods (Figure 4). Ripe mango fruits of the control group rapidly developed CI after cold storage for 21-42 days, but dipping fruits in $0.1 \mathrm{mM} \mathrm{SA}, 1 \mathrm{mM} \mathrm{SA}$ and $0.1 \mathrm{mM} \mathrm{MJ}$ significantly reduced this symptom (Figure 4). At 42 days, the CI index was significantly reduced by $17 \%, 60 \%$ and $13 \%$ in fruits treated with $0.1 \mathrm{mM} \mathrm{SA}, 1.0 \mathrm{mM}$ SA and $0.1 \mathrm{mM} \mathrm{MJ}$, respectively, compared with the control fruits (Figure 4). The treatment of $1 \mathrm{mM} \mathrm{SA}$ was the most effective at reducing the CI index of ripe fruits for all storage times (Figure 4). For the criterion of acceptability for visual marketing quality of mango fruit, it was found that dipping fruits in $0.1 \mathrm{mM} \mathrm{SA}$ and $0.1 \mathrm{mM}$ $\mathrm{MJ}$ could prolong storage time of mango fruits at $5{ }^{\circ} \mathrm{C}$ for 28 days with $\mathrm{CI}$ indices of 1.83 and 2.00, respectively, whereas the $\mathrm{CI}$ index of the control group was over 2 (Figure 4). Interestingly, the treatment of $1 \mathrm{mM} \mathrm{SA}$ could prolong the storage time up to 42 days with a CI index of 2.00 (Figure 4). 


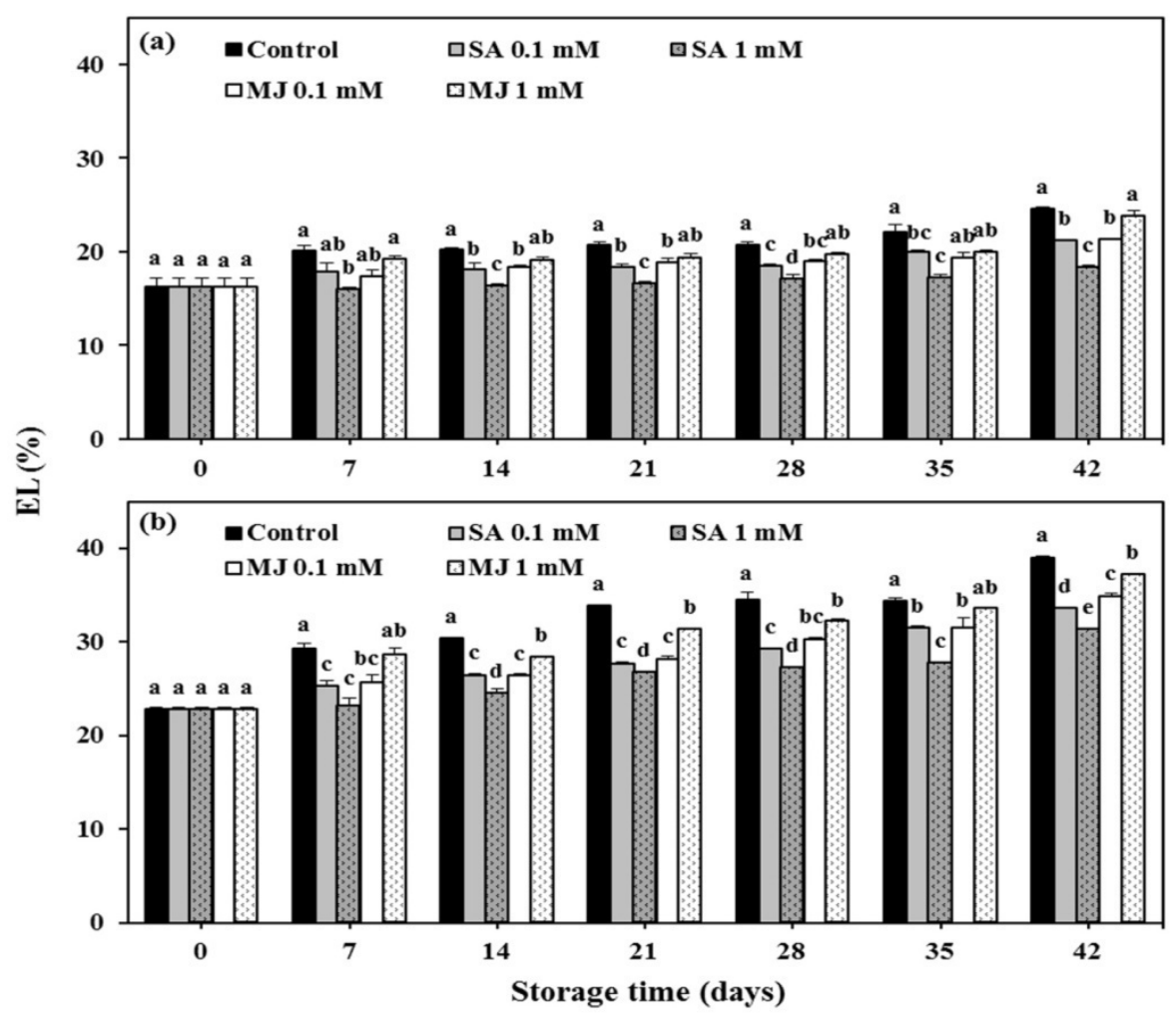

Figure 3. Effects of SA and MJ on electrolyte leakage (EL) in the skin (a) and pulp (b) of mango fruits during storage at $5{ }^{\circ} \mathrm{C}$

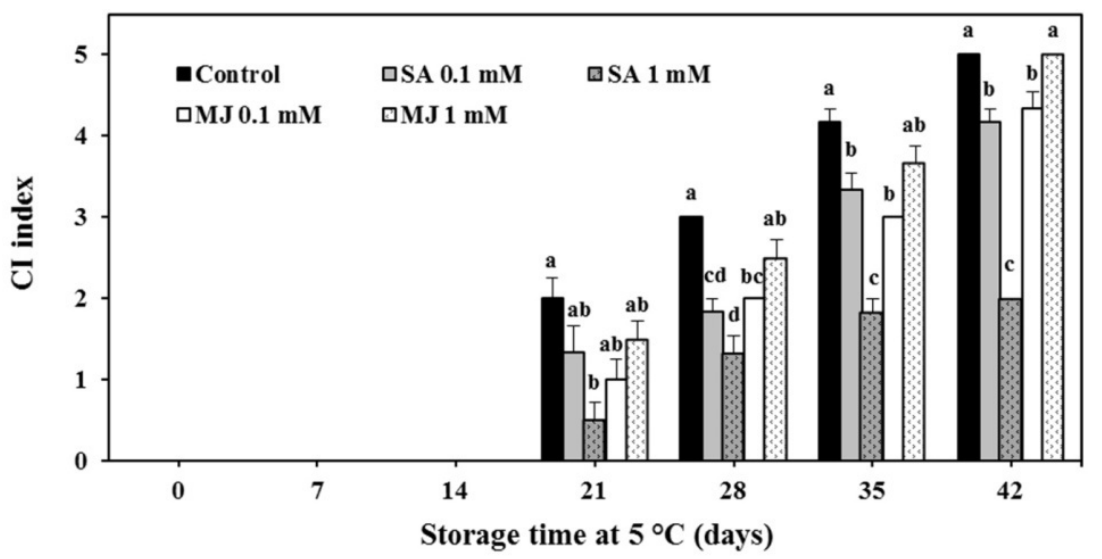

Figure 4. Effects of SA and MJ on chilling injury (CI) index of mango fruits after transfer to room temperature

\subsection{MDA Content and EL after Transfer to Room Temperature}

MDA content in both skin and pulp of ripe mango fruits in all groups increased in fruits stored for longer periods (Figures 5a, and $\mathrm{b}$ ). This increase in MDA content for all storage times was significantly reduced in fruits treated with $0.1 \mathrm{mM} \mathrm{SA}, 1 \mathrm{mM} \mathrm{SA}$ and $0.1 \mathrm{mM}$ MJ (Figures $5 \mathrm{a}$, and $\mathrm{b}$ ). The treatment of $1 \mathrm{mM} \mathrm{SA}$ was the most effective in reducing MDA content in both skin and pulp of ripe fruits (Figures 5a, and b).

EL in both skin and pulp of ripe mango fruits in the control group considerably increased in fruits stored for longer periods (Figures 6a, and b). This increase of EL for all storage times was significantly reduced in fruits treated with $0.1 \mathrm{mM} \mathrm{SA}, 1 \mathrm{mM} \mathrm{SA}$ and $0.1 \mathrm{mM} \mathrm{MJ}$ (Figures $6 \mathrm{a}$, and b). It was found that $1 \mathrm{mM} \mathrm{SA}$ was the most effective in reducing EL in both skin and pulp of ripe fruits (Figures 6a, and b). 


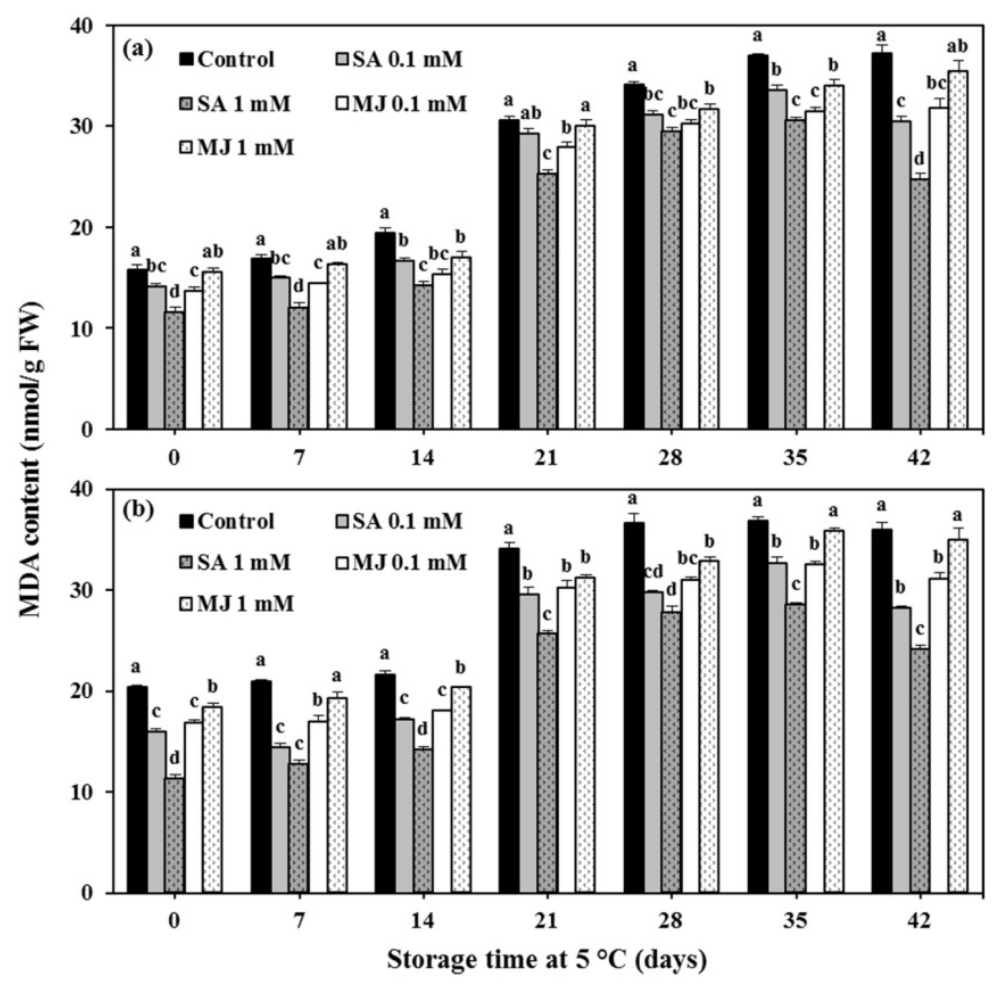

Figure 5. Effects of SA and MJ on malondialdehyde (MDA) content in the skin (a) and pulp (b) of mango fruits after transfer to room temperature

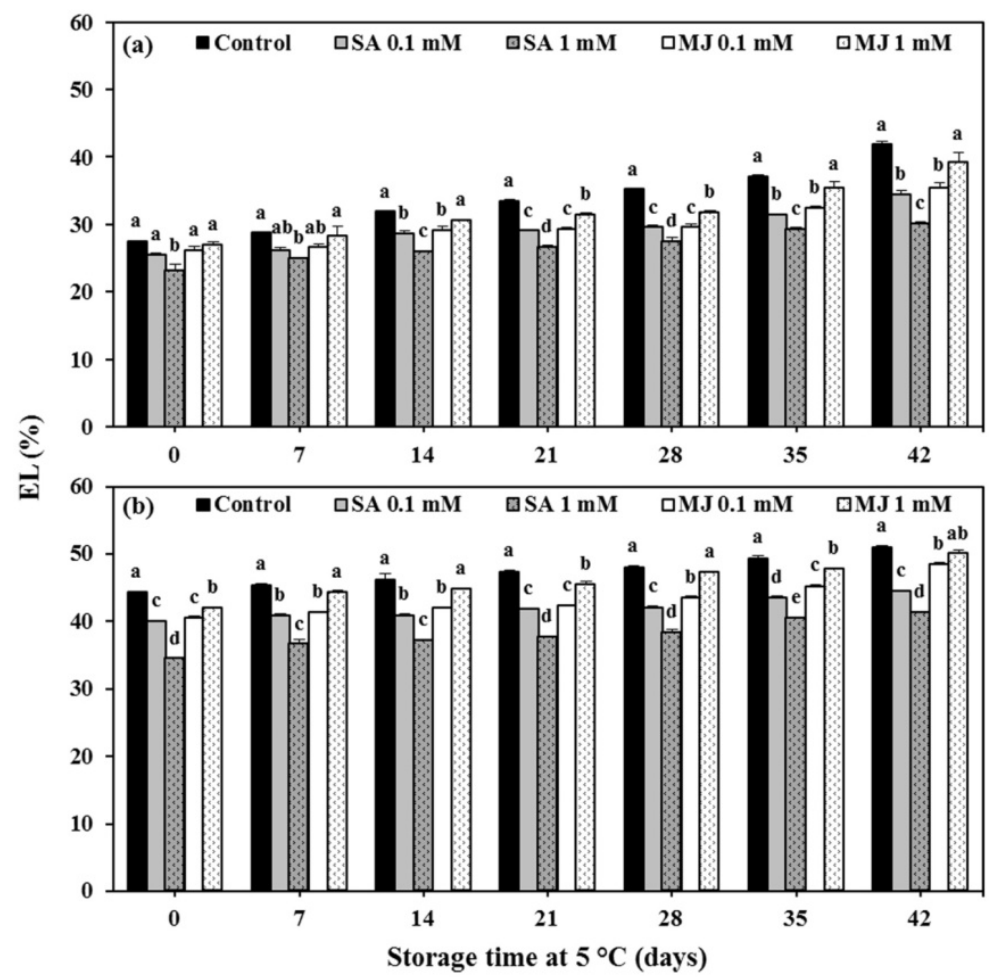

Figure 6. Effects of SA and MJ on electrolyte leakage (EL) in the skin (a) and pulp (b) of mango fruits after transfer to room temperature 
Interestingly, high positive relationships are found between CI and MDA content in skin and pulp and between $\mathrm{CI}$ and the percentage of EL of cold storage and after transfer to room temperature (Figure 7), indicating that CI in Nam Dok Mai No. 4 mango fruits correlates with changes in EL and MDA content.
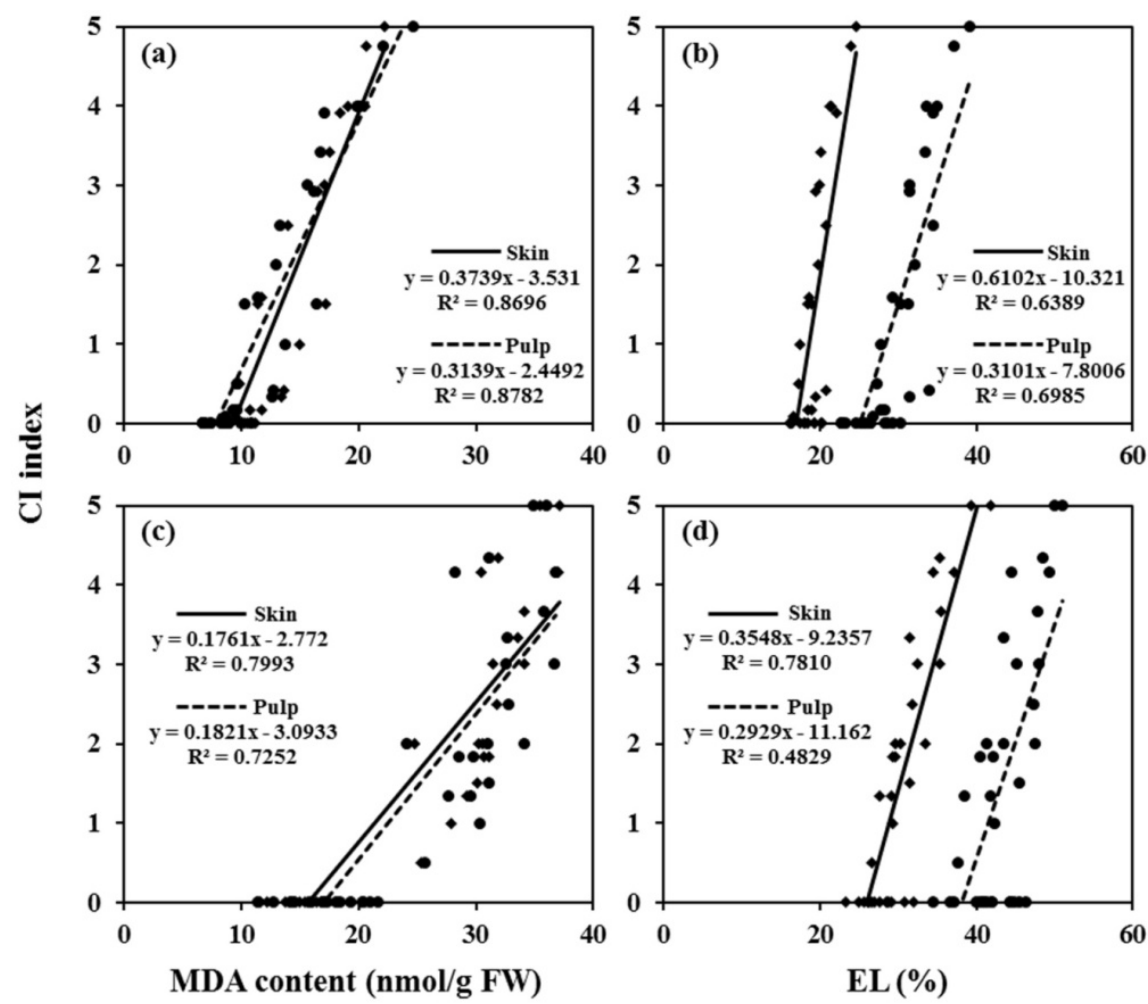

Figure 7. Correlation between the $\mathrm{CI}$ index and MDA content and percentage of EL of mango fruits during storage at $5{ }^{\circ} \mathrm{C}(\mathrm{a}, \mathrm{b})$ and after transfer to room temperature $(\mathrm{c}, \mathrm{d})$

\subsection{Ripening Quality of Mangoes after Transfer to Room Temperature}

The results showed that fruit firmness, percentages of TA and skin color $\left({ }^{\circ}\right.$ Hue values) of ripe fruits after cold storage for 7-42 days of the control, SA, and MJ treatments were not significantly different from fruits ripening at room temperature, whereas other qualities were slightly changed (Table 1).

For 7-14 days all treated and control fruits ripened normally, and their ripening qualities were not different from the fruits ripening at room temperature, except the percentage of TSS in which cold storage for 14 days significantly decreased this quality (Table 1).

Fruits stored for 21 days had lower TSS than fruits ripening at room temperature (Table 1). The number of days to ripen was affected. Mango fruits cv. Nam Dok Mai No. 4 required 10 days for ripening at room temperature, whereas this occurred in 8 days in fruits stored in the cold for 21 days before transfer to room temperature. The score of consumer acceptance for the control and the treatments was more than six, indicating that keeping fruits for 21 days in cold temperature was acceptable for ripening qualities.

For fruits ripening after cold storage for 28 days, all treatments and the control had lower TSS and number of days to ripen than fruits ripening at room temperature (Table 1). The score of consumer acceptance in the control group was lower than six. This score in SA and MJ treated fruits was about six to seven and was not significantly different from that of fruits ripened at room temperature (Table 1). The disease index (DI) for the control and SA treatments was not different from that of normal fruits, whereas the DI in MJ treated fruits was higher than in normally ripened fruits (Table 1).

At 35 days, TSS of the control and $1 \mathrm{mM} \mathrm{SA}$ treated fruits was higher than other treatments and was not significantly different from that of normally ripened fruits (Table 1). All treatments and the control had a higher DI and lower number of days to ripen than those of normally ripened fruits (Table 1). Treatments of $0.1 \mathrm{mM}$ and $1 \mathrm{mM} \mathrm{SA}$ had score of consumer acceptance of 6.4 and 6.8 , respectively, whereas in other treatments and the control fruits, this score was lower than six (Table 1). 
Table 1. Data on the number of days to ripen, skin color $\left({ }^{\circ}\right.$ Hue values), firmness, total soluble solids (TSS), total acidity (TA), disease index, and scores of consumer acceptance of normally ripened fruits at room temperature compared with fruits ripened at room temperature after cold storage for $7,14,21,28,35$, and 42 days

\begin{tabular}{|c|c|c|c|c|c|c|c|c|}
\hline Day & Treatment & $\begin{array}{l}\text { Number of } \\
\text { days to ripen }\end{array}$ & ${ }^{\circ}$ Hue values & $\begin{array}{l}\text { Firmness } \\
\left(\mathrm{kg} / \mathrm{cm}^{2}\right)\end{array}$ & TSS (\% brix) & TA $(\%)$ & Disease index & $\begin{array}{l}\text { Score of } \\
\text { consumer } \\
\text { acceptance }\end{array}$ \\
\hline & $\begin{array}{l}\text { Normally } \\
\text { ripened }\end{array}$ & $10.2 \pm 0.5 \mathrm{a}$ & $78.83 \pm 0.64 \mathrm{a}$ & $0.64 \pm 0.02 \mathrm{a}$ & $15.73 \pm 0.05 \mathrm{a}$ & $0.11 \pm 0.01 \mathrm{a}$ & $0.18 \pm 0.12 \mathrm{a}$ & $8.2 \pm 0.2 \mathrm{a}$ \\
\hline \multirow[t]{5}{*}{7} & Control & $9.2 \pm 0.5 \mathrm{a}$ & $79.21 \pm 0.56 \mathrm{a}$ & $0.65 \pm 0.03 \mathrm{a}$ & $14.57 \pm 0.16 \mathrm{a}$ & $0.11 \pm 0.00 \mathrm{a}$ & $0.55 \pm 0.16 \mathrm{a}$ & $7.8 \pm 0.2 \mathrm{a}$ \\
\hline & SA $0.1 \mathrm{mM}$ & $9.6 \pm 0.4 \mathrm{a}$ & $79.39 \pm 0.74 \mathrm{a}$ & $0.69 \pm 0.02 \mathrm{a}$ & $14.86 \pm 0.18 \mathrm{a}$ & $0.12 \pm 0.00 \mathrm{a}$ & $0.18 \pm 0.12 \mathrm{a}$ & $8.0 \pm 0.4 \mathrm{a}$ \\
\hline & $\mathrm{SA} 1 \mathrm{mM}$ & $9.2 \pm 0.5 \mathrm{a}$ & $79.75 \pm 0.80 \mathrm{a}$ & $0.69 \pm 0.02 \mathrm{a}$ & $14.89 \pm 0.84 \mathrm{a}$ & $0.12 \pm 0.00 \mathrm{a}$ & $0.36 \pm 0.15 \mathrm{a}$ & $7.8 \pm 0.2 \mathrm{a}$ \\
\hline & MJ $0.1 \mathrm{mM}$ & $9.6 \pm 0.4 \mathrm{a}$ & $79.62 \pm 0.86 \mathrm{a}$ & $0.65 \pm 0.03 \mathrm{a}$ & $14.70 \pm 0.07 \mathrm{a}$ & $0.12 \pm 0.00 \mathrm{a}$ & $0.09 \pm 0.09 \mathrm{a}$ & $7.6 \pm 0.4 \mathrm{a}$ \\
\hline & MJ $1 \mathrm{mM}$ & $8.8 \pm 0.5 \mathrm{a}$ & $79.23 \pm 0.75 \mathrm{a}$ & $0.69 \pm 0.02 \mathrm{a}$ & $14.51 \pm 0.17 \mathrm{a}$ & $0.11 \pm 0.00 \mathrm{a}$ & $0.36 \pm 0.15 \mathrm{a}$ & $7.8 \pm 0.2 \mathrm{a}$ \\
\hline \multirow[t]{5}{*}{14} & Control & $8.8 \pm 0.5 \mathrm{a}$ & $79.11 \pm 0.63 \mathrm{a}$ & $0.61 \pm 0.03 \mathrm{a}$ & $14.19 \pm 0.17 \mathrm{~b}$ & $0.11 \pm 0.01 \mathrm{a}$ & $0.64 \pm 0.15 \mathrm{a}$ & $7.6 \pm 0.2 \mathrm{a}$ \\
\hline & SA $0.1 \mathrm{mM}$ & $9.0 \pm 0.4 \mathrm{a}$ & $79.17 \pm 0.57 \mathrm{a}$ & $0.60 \pm 0.04 \mathrm{a}$ & $14.27 \pm 0.11 \mathrm{~b}$ & $0.12 \pm 0.00 \mathrm{a}$ & $0.45 \pm 0.16 \mathrm{a}$ & $8.0 \pm 0.3 \mathrm{a}$ \\
\hline & $\mathrm{SA} 1 \mathrm{mM}$ & $8.8 \pm 0.4 \mathrm{a}$ & $79.16 \pm 0.89 \mathrm{a}$ & $0.60 \pm 0.02 \mathrm{a}$ & $14.55 \pm 0.14 \mathrm{~b}$ & $0.12 \pm 0.00 \mathrm{a}$ & $0.55 \pm 0.16 \mathrm{a}$ & $7.8 \pm 0.4 \mathrm{a}$ \\
\hline & MJ $0.1 \mathrm{mM}$ & $8.8 \pm 0.5 \mathrm{a}$ & $80.44 \pm 0.70 \mathrm{a}$ & $0.61 \pm 0.03 \mathrm{a}$ & $14.34 \pm 0.10 \mathrm{~b}$ & $0.11 \pm 0.01 \mathrm{a}$ & $0.64 \pm 0.15 \mathrm{a}$ & $7.6 \pm 0.2 \mathrm{a}$ \\
\hline & $\mathrm{MJ} 1 \mathrm{mM}$ & $8.6 \pm 0.4 \mathrm{a}$ & $79.39 \pm 0.98 \mathrm{a}$ & $0.61 \pm 0.03 \mathrm{a}$ & $14.63 \pm 0.07 \mathrm{~b}$ & $0.11 \pm 0.00 \mathrm{a}$ & $0.55 \pm 0.16 \mathrm{a}$ & $8.2 \pm 0.2 \mathrm{a}$ \\
\hline \multirow[t]{5}{*}{21} & Control & $8.2 \pm 0.4 b$ & $79.30 \pm 0.55 \mathrm{a}$ & $0.61 \pm 0.01 \mathrm{a}$ & $14.43 \pm 0.12 \mathrm{~b}$ & $0.12 \pm 0.00 \mathrm{a}$ & $0.82 \pm 0.18 \mathrm{a}$ & $6.4 \pm 0.2 \mathrm{~b}$ \\
\hline & SA $0.1 \mathrm{mM}$ & $8.6 \pm$ & $79.91 \pm 0.78 \mathrm{a}$ & & $14.56 \pm 0$ & & & $7.6 \pm 0.2 \mathrm{ab}$ \\
\hline & $\mathrm{SA} 1 \mathrm{mM}$ & $8.4 \pm 0.2 b$ & $79.83 \pm 0.84 \mathrm{a}$ & $0.61 \pm 0.03 \mathrm{a}$ & $14.41 \pm 0.27 \mathrm{~b}$ & $0.12 \pm 0.00 \mathrm{a}$ & $0.73 \pm 0.14 \mathrm{a}$ & $7.4 \pm 0.2 \mathrm{ab}$ \\
\hline & MJ $0.1 \mathrm{mM}$ & $8.0 \pm 0.3 b$ & $79.74 \pm 0.64 \mathrm{a}$ & $0.59 \pm 0.02 \mathrm{a}$ & $14.14 \pm 0.38 \mathrm{~b}$ & $0.12 \pm 0.00 \mathrm{a}$ & $0.64 \pm 0.15 \mathrm{a}$ & $7.6 \pm 0.2 \mathrm{ab}$ \\
\hline & MJ $1 \mathrm{mM}$ & $8.0 \pm 0.0 \mathrm{~b}$ & $79.47 \pm 0.74 \mathrm{a}$ & $0.62 \pm 0.02 \mathrm{a}$ & $14.32 \pm 0.20 \mathrm{~b}$ & $0.11 \pm 0.00 \mathrm{a}$ & $0.82 \pm 0.18 \mathrm{a}$ & $7.0 \pm 0.4 \mathrm{ab}$ \\
\hline \multirow[t]{5}{*}{28} & Control & $8.8 \pm 0.2 b$ & $79.81 \pm 0.96 \mathrm{a}$ & $0.61 \pm 0.04 \mathrm{a}$ & $14.61 \pm 0.09 \mathrm{~b}$ & $0.12 \pm 0.00 \mathrm{a}$ & $0.73 \pm 0.14 a b$ & $5.6 \pm 0.2 \mathrm{c}$ \\
\hline & SA $0.1 \mathrm{mM}$ & $8.4 \pm 0.2 b$ & $79.65 \pm 0.65 \mathrm{a}$ & $0.61 \pm 0.03 \mathrm{a}$ & $14.20 \pm 0.14 \mathrm{~b}$ & $0.13 \pm 0.01 \mathrm{a}$ & $0.82 \pm 0.18 a b$ & $7.2 \pm 0.4 \mathrm{ab}$ \\
\hline & $\mathrm{SA} 1 \mathrm{mM}$ & $8.6 \pm 0.2 b$ & $80.94 \pm 0.76 \mathrm{a}$ & $0.62 \pm 0.02 \mathrm{a}$ & $14.30 \pm 0.16 \mathrm{~b}$ & $0.13 \pm 0.01 \mathrm{a}$ & $0.73 \pm 0.14 \mathrm{ab}$ & $7.0 \pm 0.3 \mathrm{ab}$ \\
\hline & MJ $0.1 \mathrm{mM}$ & $8.6 \pm 0.2 b$ & $79.91 \pm 0.48 \mathrm{a}$ & $0.61 \pm 0.03 \mathrm{a}$ & $14.11 \pm 0.31 \mathrm{~b}$ & $0.13 \pm 0.01 \mathrm{a}$ & $1.27 \pm 0.24 \mathrm{~b}$ & $7.2 \pm 0.4 \mathrm{ab}$ \\
\hline & $\mathrm{MJ} 1 \mathrm{mM}$ & $8.2 \pm 0.2 b$ & $80.45 \pm 0.86 \mathrm{a}$ & $0.56 \pm 0.01 \mathrm{a}$ & $14.19 \pm 0.17 \mathrm{~b}$ & $0.13 \pm 0.01 \mathrm{a}$ & $1.18 \pm 0.18 b$ & $6.4 \pm 0.2 \mathrm{bc}$ \\
\hline \multirow[t]{5}{*}{35} & Control & $8.0 \pm 0.3 b$ & $80.51 \pm 0.49 \mathrm{a}$ & $0.62 \pm 0.02 \mathrm{a}$ & $14.65 \pm 0.33 \mathrm{ab}$ & $0.14 \pm 0.01 \mathrm{a}$ & $1.00 \pm 0.13 b$ & $4.4 \pm 0.2 \mathrm{~d}$ \\
\hline & SA $0.1 \mathrm{mM}$ & $8.2 \pm 0.2 b$ & $80.99 \pm 0.06 \mathrm{a}$ & $0.63 \pm 0.02 \mathrm{a}$ & $14.28 \pm 0.20 \mathrm{~b}$ & $0.13 \pm 0.01 \mathrm{a}$ & $1.00 \pm 0.13 \mathrm{~b}$ & $6.4 \pm 0.2 \mathrm{bc}$ \\
\hline & $\mathrm{SA} 1 \mathrm{mM}$ & $8.0 \pm 0.0 \mathrm{~b}$ & $81.02 \pm 0.86 \mathrm{a}$ & $0.69 \pm 0.02 \mathrm{a}$ & $14.64 \pm 0.09 \mathrm{ab}$ & $0.13 \pm 0.01 \mathrm{a}$ & $1.09 \pm 0.09 \mathrm{~b}$ & $6.8 \pm 0.2 \mathrm{~b}$ \\
\hline & MJ $0.1 \mathrm{mM}$ & $8.4 \pm 0.2 b$ & $80.16 \pm 0.69 \mathrm{a}$ & $0.63 \pm 0.03 \mathrm{a}$ & $14.55 \pm 0.15 \mathrm{~b}$ & $0.14 \pm 0.01 \mathrm{a}$ & $1.27 \pm 0.24 \mathrm{~b}$ & $5.8 \pm 0.4 b c$ \\
\hline & MJ $1 \mathrm{mM}$ & $8.2 \pm 0.2 b$ & $81.16 \pm 0.64 \mathrm{a}$ & $0.68 \pm 0.02 \mathrm{a}$ & $14.00 \pm 0.48 \mathrm{~b}$ & $0.13 \pm 0.01 \mathrm{a}$ & $1.27 \pm 0.27 \mathrm{~b}$ & $5.4 \pm 0.2 \mathrm{~cd}$ \\
\hline \multirow[t]{5}{*}{42} & Control & $7.8 \pm 0.2 b$ & $81.24 \pm 0.65 \mathrm{a}$ & $0.63 \pm 0.03 \mathrm{a}$ & $14.24 \pm 0.25 \mathrm{~b}$ & $0.14 \pm 0.01 \mathrm{a}$ & $1.18 \pm 0.30 \mathrm{~b}$ & $3.6 \pm 0.2 \mathrm{~d}$ \\
\hline & SA $0.1 \mathrm{mM}$ & $8.0 \pm 0.3 b$ & $80.78 \pm 0.23 \mathrm{a}$ & $0.66 \pm 0.03 \mathrm{a}$ & $14.55 \pm 0.25 \mathrm{~b}$ & $0.13 \pm 0.01 \mathrm{a}$ & $1.36 \pm 0.15 \mathrm{~b}$ & $5.4 \pm 0.2 \mathrm{c}$ \\
\hline & $\mathrm{SA} 1 \mathrm{mM}$ & $8.4 \pm 0.2 b$ & $80.33 \pm 0.92 \mathrm{a}$ & $0.64 \pm 0.02 \mathrm{a}$ & $14.42 \pm 0.15 \mathrm{~b}$ & $0.13 \pm 0.01 \mathrm{a}$ & $1.27 \pm 0.19 b$ & $6.6 \pm 0.2 \mathrm{~b}$ \\
\hline & MJ $0.1 \mathrm{mM}$ & $8.6 \pm 0.4 b$ & $80.29 \pm 0.86 \mathrm{a}$ & $0.61 \pm 0.02 \mathrm{a}$ & $14.42 \pm 0.22 \mathrm{~b}$ & $0.13 \pm 0.01 \mathrm{a}$ & $1.18 \pm 0.18 \mathrm{~b}$ & $5.6 \pm 0.2 \mathrm{bc}$ \\
\hline & MJ $1 \mathrm{mM}$ & $8.4 \pm 0.2 \mathrm{~b}$ & $81.11 \pm 0.90 \mathrm{a}$ & $0.62 \pm 0.02 \mathrm{a}$ & $14.22 \pm 0.20 \mathrm{~b}$ & $0.13 \pm 0.01 \mathrm{a}$ & $1.55 \pm 0.16 \mathrm{~b}$ & $4.6 \pm 0.4 \mathrm{~cd}$ \\
\hline
\end{tabular}

Means \pm S.E. with the same letter within the column between normally ripened fruits and cold stored fruits are not significantly different according to Tukey's test $(\mathrm{p}<0.05)$.

At 42 days, SA and MJ treated fruits after cold storage, the TSS and number of days to ripen of the control and treatments were lower than those of normally ripened fruits, whereas the DI was higher (Table 1). Interestingly, fruits treated with $1 \mathrm{mM} \mathrm{SA}$ had a consumer acceptance score of 6.6, whereas this score in the other treatments and the control was lower than six (Table 1).

\section{Discussion}

Nam Dok Mai No. 4 mango fruits showed CI symptoms such as skin browning and surface pitting after 21 days of storage at $5{ }^{\circ} \mathrm{C}$. These symptoms were more severe when fruits were transferred to room temperature for 
ripening, but at this storage time, the fruits were still acceptable as the $\mathrm{CI}$ index was lower than 2 (Figures 1 and 4). At 28 days of cold storage, fruits in the control group and $1 \mathrm{mM} \mathrm{MJ}$ treatment were unacceptable since the CI index was over than 2. Fruits dipped in $0.1 \mathrm{mM} \mathrm{SA}, 1 \mathrm{mM} \mathrm{SA}$ and $0.1 \mathrm{mM} \mathrm{MJ}$ maintained their quality (Figures 1 and 4). The CI index of $0.1 \mathrm{mM} \mathrm{SA}$ and $0.1 \mathrm{mM}$ MJ was unacceptable after 35 days, whereas $1 \mathrm{mM} \mathrm{SA}$ treatment prolonged storage time of the fruits until 42 days (Figures 1 and 4). These results indicate that SA and MJ treatments reduced CI symptoms in mango fruits. Our results are consistent with Ding et al. (2007) and González-Aguilar et al. (2000, 2001) who reported that CI symptoms in mango fruits cvs. Zill, Tommy Atkins and Kent during cold storage and after transfer to room temperature were reduced by SA and MJ treatments.

It has been reported that $\mathrm{CI}$ is caused by physiological changes in the cell membrane, where the liquid-crystalline state is changed to a solid gel state and this rigidity of the cell membrane causes EL from the cell (Lyons, 1973). In addition, the content of MDA, a secondary end product of polyunsaturated fatty acid oxidation, has also been reported to increase during low temperature storage (Zhao et al., 2006). MDA is usually considered as an indicator for the structural integrity of the membranes of plants subjected to low temperatures (Hodges et al., 1999). In our study, EL and MDA content in the skin and pulp of Nam Dok Mai No. 4 increased during storage at $5{ }^{\circ} \mathrm{C}$ (Figures 2 and 3 ) and rapidly increased when the fruits were transferred to room temperature (Figures 5 and 6). Interestingly, the increase in EL and MDA content appeared before the CI symptoms (Figures 1-6). This result suggests that oxidative stress is an early response of mango fruits to chilling injury as it initiates membrane degradation causing lipid peroxidation (Shewfelt and del Rosario, 2000). Our results are consistent with previous studies by González-Aguilar et al. (2000), Zhao et al. (2006), Ding et al. (2007) and Wang et al. (2008) who found that EL and MDA content increased in Tommy Atkins, Wacheng, Zill, and Tainong mango fruits during storage at $2-7^{\circ} \mathrm{C}$ for $7-30$ days.

Although EL and MDA content increased during storage at $5{ }^{\circ} \mathrm{C}$, these parameters decreased in fruits treated with SA and MJ treatments (Figures 2 and 3). The result agrees with Ding et al. (2007) who reported that SA reduced MDA content of Zill mango fruits during storage at $5{ }^{\circ} \mathrm{C}$ for 30 days. This result is also consistent with González-Aguilar et al. (2000) who found that MJ treatment reduced EL during storage at $7{ }^{\circ} \mathrm{C}$ for 21 days of mango cv. Tommy Atkins. Our results also showed that Nam Dok Mai No. 4 treated with SA and MJ had lower EL and MDA content than those of the control when fruits were transferred to room temperature for ripening (Figures 5 and 6). This result is consistent with previous studies by González-Aguilar et al. (2000) and Ding et al. (2007) who reported that SA and MJ treatments reduced EL and MDA in mango fruits cvs. Tommy Atkins and Zill after transfer to room temperature for ripening. A possible explanation for the effectiveness of SA and MJ in reducing CI in Nam Dok Mai No. 4 is that SA and MJ reduce lipid peroxidation of cell membranes and maintain membrane integrity with low EL and MDA content in the fruits during cold storage and ripening at room temperature, causing a reduction in CI symptoms. González-Aguilar et al. (2000 \& 2004), Wang et al. (2006), Ding et al. (2007) and Sayyari et al. (2009) also demonstrated that SA or MJ treatments alleviated CI together with the reduction of EL or MDA content in mangoes, guava, peach, and pomegranate fruits.

Another possible reason is that SA and MJ might enhance antioxidative defense systems such as antioxidant enzyme activity and antioxidant contents in mango fruits (Ding et al., 2007; Cao et al., 2009). Increases in catalase, ascorbate peroxidase, superoxide dismutase, guaiacol peroxidase and glutathione reductase activities, and in content of ascorbic acid and glutathione were observed in Zill mangoes treated by SA (Ding et al., 2007). The increase of catalase, ascorbate peroxidase, and superoxide dismutase activities were found in loquat fruits treated with MJ (Cao et al., 2009).

The effectiveness of SA and MJ in reducing chilling injury depends on the species or cultivar (Ding et al., 2002; Fung et al., $2004 \&$ 2006). In our experiment, $1 \mathrm{mM}$ SA treatment was more effective in reducing chilling injury than MJ treatments during cold storage at $5{ }^{\circ} \mathrm{C}$ and after transfer to room temperature for ripening (Figures 1 and 4). A possible reason is that SA treatment reduces lipid peroxidation of cell membranes and maintains membrane integrity more effectively than MJ treatments. This explanation is supported by the results shown in Figures 2, 3, 5 , and 6 in which fruits treated with SA had a lower percentage of EL and MDA content than those of MJ treated fruits. Our results agree with Fung et al. (2006) who reported that treatment with methyl salicylate (MeSA), a derivative of SA, was more efficient in reducing CI symptoms of tomato fruit (Lycopersicon esculentum L.) than MJ treatments, but in sweet peppers (Capsicum annuum L.), MJ treatments were more effective than MeSA (Fung et al. 2004). In addition to the species or cultivar, the effectiveness of SA and MJ in reducing chilling injury also depends on the concentrations used (González-Aguilar et al., 2001; Wang et al., 2006; Sayyari et al., 2009). We found that $1 \mathrm{mM} \mathrm{SA}$ was more effective than $0.1 \mathrm{mM} \mathrm{SA}$ (Figures 1 and 4). This is in agreement with Wang et al. (2006) and Sayyari et al. (2009) who reported that the highest SA concentrations (1 mM and $2 \mathrm{mM})$ were the most effective to reduce CI symptoms of peach and pomegranate fruits. 
SA and MJ treatments not only reduced CI symptoms, MDA and EL of Nam Dok Mai No.4 mangoes during cold storage at $5{ }^{\circ} \mathrm{C}$ and at the ripening stage at room temperature, but also prolonged storage life. The score of consumer acceptance showed that the control fruits were unacceptable after storage in cold temperature for 28 days with a score of consumer acceptance lower than six, whereas fruits treated with SA or MJ were still acceptable (Table 1). The treatment of $0.1 \mathrm{mM}$ SA prolonged high fruit quality up to 35 days, while $1 \mathrm{mM}$ SA did this until 42 days (Table 1). Fruit firmness, percentages of TA and skin color ( ${ }^{\circ}$ Hue values) of ripe fruits after cold storage for 7-42 days were not significantly different between normally ripened fruits and all SA and MJ treatments, except TSS and days to ripen which were lower and shorter than those of normally ripened fruits (Table 1). This indicates that SA and MJ treatments maintained high fruit quality. Our results agree with those of Ding et al. (2007) who showed that the quality of ripening mango cv. Zill was not obviously affected by pretreatment with SA. González-Aguilar et al. (2000 \& 2001) also found that MJ treatment did not affect ripening qualities of mango cv. Tommy Atkins and Kent. It is interesting to note that although $1 \mathrm{mM} \mathrm{SA}$ could prolong fruit quality up to 42 days, this treatment could not control disease of the fruits. Further experiments need to be done to overcome this problem.

\section{Conclusions}

Nam Dok Mai No. 4 mango fruits showed CI symptoms after 21 days of storage at $5{ }^{\circ} \mathrm{C}$ and were unacceptable for consumption after 28 days of cold storage followed by to room temperature. Dipping fruits in $0.1 \mathrm{mM} \mathrm{MJ}$, $1 \mathrm{mM} \mathrm{MJ}$ and $0.1 \mathrm{mM} \mathrm{SA}$ reduced CI of cold storage and after transfer to room temperature for up to 35 days. Dipping in $1 \mathrm{mM}$ SA prolonged fruit quality up to 42 days without affecting fruit firmness, percentages of TA, and skin color ( ${ }^{\circ}$ Hue values) of ripe fruits.

\section{Acknowledgments}

We thank Dr. J. F. Maxwell of the Department of Biology, Faculty of Science, Chiang Mai University for proof reading this manuscript. This research was supported by the Postharvest Technology Innovation Center, Commission on Higher Education, Bangkok, Thailand and by the Graduate School, Chiang Mai University, Chiang Mai, Thailand.

\section{References}

Ananieva, E. A., Christov, K. N., \& Popova, L. P. (2004). Exogenous treatment with salicylic acid leads to increased antioxidant capacity in leaves of barley plants exposed to paraquat. Journal of Plant Physiology, 161, 319-328. http://dx.doi.org/10.1078/0176-1617-01022

AOAC. (1990). Official Methods of Analysis (15th ed.). Association of Official Analytical Chemists, Washington, D.C.

Cao, S., Zheng, Y., Wang, K., Jin, P., \& Rui, H. (2009). Methyl jasmonate reduces chilling injury and enhances antioxidant enzyme activity in postharvest loquat fruit. Food Chemistry, 115, 1458-1463. http://dx.doi.org/10.1016/j.foodchem.2009.01.082

Chan, H. T. JR., Sanxter, S., \& Couey, H. M. (1985). Electrolyte leakage and ethylene production induced by chilling injury of papayas. Hort Science, 20, 1070-1072.

Creelman, R. A., \& Mullet, J. E. (1997). Biosynthesis and action of jasmonates in plants. Annual Review of Plant Physiology and Plant Molecular Biology, 48, 355-381. http://dx.doi.org/10.1146/annurev.arplant.48.1.355

Ding, C. K., Wang, C. Y., Gross, K. C., \& Smith, D. L. (2002). Jasmonate and salicylate induce the expression of pathogenesis-related-protein genes and increase resistance to chilling injury in tomato fruit. Planta, 214, 895-901. http://dx.doi.org/10.1007/s00425-001-0698-9

Ding, Z. S., Tian, S. P., Zheng, X. L., Zhou, Z. W., \& Xu, Y. (2007). Responses of reactive oxygen metabolism and quality in mango fruit to exogenous oxalic acid or salicylic acid under chilling temperature stress. Physiologia Plantarum, 130, 112-121. http://dx.doi.org/10.1111/j.1399-3054.2007.00893.x

Fung, R. W. M., Wang, C. Y., Smith, D. L., Gross, K. C., Tao, Y., \& Tian, M. (2006). Characterization of alternative oxidase (AOX) gene expression in response to methyl salicylate and methyl jasmonate pre-treatment and low temperature in tomatoes. Journal of Plant Physiology, 163, 1049-1060. http://dx.doi.org/10.1016/j.jplph.2005.11.003

Fung, R. W. M., Wang, C. Y., Smith, D. L., Gross, K. C., \& Tian, M. (2004). MeSA and MeJA increase steady-state transcript levels of alternative oxidase and resistance against chilling injury in sweet peppers (Capsicum annuum L.). Plant Science, 166, 711-719. http://dx.doi.org/10.1016/j.plantsci.2003.11.009 
González-Aguilar, G. A., Buta, J. G., \& Wang, C. Y. (2001). Methyl jasmonate reduces chilling injury symptoms and enhances colour development of 'Kent' mangoes. Journal of the Science of Food and Agriculture, 81, 1244-1249. http://dx.doi.org/10.1002/jsfa.933

González-Aguilar, G. A., Fortiz, J., Cruz, R., Baez, R., \& Wang, C. Y. (2000). Methyl jasmonate reduces chilling injury and maintains postharvest quality of mango fruit. Journal of Agricultural and Food Chemistry, 48, 515-519. http://dx.doi.org/10.1021/jf9902806

González-Aguilar, G. A., Tiznado-Hernández, M. E., Zavaleta-Gatica, R., \& Martínez-Téllez, M. A. (2004). Methyl jasmonate treatments reduce chilling injury and activate the defense response of guava fruits. Biochemical and Biophysical Research Communications, 313, 694-701. http://dx.doi.org/10.1016/j.bbrc.2003.11.165

Hodges, D. M., DeLong, J. M., Forney, C. F., \& Prange, R. K. (1999). Improving the thiobarbituric acid-reactive-substances assay for estimating lipid peroxidation in plant tissues containing anthocyanin and other interfering compounds. Planta, 207, 604-611. http://dx.doi.org/10.1007/s004250050524

Jin, P., Zheng, Y., Tang, S., Rui, H., \& Wang, C. Y. (2009). A combination of hot air and methyl jasmonate vapor treatment alleviates chilling injury of peach fruit. Postharvest Biology and Technology, 52, 24-29. http://dx.doi.org/10.1016/j.postharvbio.2008.09.011

Kumpoun, W., \& Uthaibutra, J. (2010). Storage life extension of exported 'Nam Dok Mai' mango by refrigerated modified atmosphere packing. Acta Horticulturae, 876, 221-226.

Lim, C. S., Kang, S. M., Cho, J. L., \& Gross, K. C. (2009). Antioxidizing enzyme activities in chilling-sensitive and chilling-tolerant pepper fruit as affected by stage of ripeness and storage temperature. Journal of the American Society for Horticultural Science, 134, 156-163.

Lyons, J. M. (1973). Chilling injury in plants. Annual Review of Plant Physiology, 24, 445-466. http://dx.doi.org/10.1146/annurev.pp.24.060173.002305

Meng, X., Han, J., Wang, Q., \& Tian, S. (2009). Changes in physiology and quality of peach fruits treated by methyl jasmonate under low temperature stress. Food Chemistry, 114, 1028-1035. http://dx.doi.org/10.1016/j.foodchem.2008.09.109

Mohammed, M., \& Brecht, J. K. (2002). Reduction of chilling injury in 'Tommy Atkins' mangoes during ripening. Scientia Horticulturae, 95, 297-308. http://dx.doi.org/10.1016/S0304-4238(02)00041-9

Phakawatmongkol, W., Ketsa, S., \& van Doorn, W. G. (2004). Variation in fruit chilling injury among mango cultivars. Postharvest Biology and Technology, 32, 115-118. http://dx.doi.org/10.1016/j.postharvbio.2003.11.011

Raskin, I. (1992). Salicylate, a new plant hormone. Plant Physiology, 99, 799-803. http://dx.doi.org/10.1104/pp.99.3.799

Sayyari, M., Babalar, M., Kalantari, S., Serrano, M., \& Valero, D. (2009). Effect of salicylic acid treatment on reducing chilling injury in stored pomegranates. Postharvest Biology and Technology, 53, 152-154. http://dx.doi.org/10.1016/j.postharvbio.2009.03.005

Shewfelt, R. L., \& del Rosario, B. A. (2000). The role of lipid peroxidation in storage disorders of fresh fruits and vegetable. HortScience, 35, 575-579.

Wang, L., Chen, S., Kong, W., Li, S., \& Archbold, D. D. (2006). Salicylic acid pretreatment alleviates chilling injury and affects the antioxidant system and heat shock proteins of peaches during cold storage. Postharvest Biology and Technology, 41, 244-251. http://dx.doi.org/10.1016/j.postharvbio.2006.04.010

Wang, B., Wang, J., Liang, H., Yi, J., Zhang, J., Lin, L., Wu, Y., Feng, X., Cao, J., \& Jiang, W. (2008). Reduced chilling injury in mango fruit by 2,4-dichlorophenoxyacetic acid and the antioxidant response. Postharvest Biology and Technology, 48, 172-181. http://dx.doi.org/10.1016/j.postharvbio.2007.10.005

Wills, R., McGlasson, B., Graham, D., \& Joyce, D. (1998). Postharvest: An Introduction to the Physiology and Handling of Fruit, Vegetables and Ornamentals (4th ed.). Cab International, New York.

Zhao, Z., Jiang, W., Cao, J., Zhao, Y., \& Gu, Y. (2006). Effect of cold-shock treatment on chilling injury in mango (Mangifera indica L. cv. 'Wacheng') fruit. Journal of the Science of Food and Agriculture, 86, 2458-2462. http://dx.doi.org/10.1002/jsfa.2640 